\title{
Chlorothalonil, Trifloxystrobin, and Mancozeb Decrease Anthracnose Symptoms on Three Cultivars of Wintercreeper Euonymus
}

\author{
Stephanie L. Schupbach-Ningen ${ }^{1}$, Janet C. Cole ${ }^{2}$, \\ James T. Cole ${ }^{3}$, and Kenneth E. Conway ${ }^{4}$
}

AdDitional INDEX wORDs. Colletotrichum gloeosporioides, Euonymus fortunei, fungicide, chemical control, leaf spot, stem lesion

Summary. The effectiveness of chlorothalonil, mancozeb, and trifloxystrobin applied alone or in rotations of two or three fungicides to control anthracnose symptoms caused by Colletotrichum gloeosporioides was evaluated on three cultivars of field- and container-grown wintercreeper euonymus (Euonymus fortunei) during the 2001 growing season. Studies were conducted at Stillwater, Okla.; Fayetteville, Ark.; and Park Hill, Okla. Rooted cuttings of wintercreeper euonymus 'Emerald Gaiety', 'Emerald 'n Gold', and 'Emerald Surprise' were transplanted from 1-gal plastic containers into field soil at the Oklahoma State University Nursery Research Station and at the University of Arkansas Horticulture Farm on 10 May 2001. In a parallel study, recently transplanted rooted cuttings of the same cultivars in 1-gal pots containing substrate consisting of pine bark and sand were placed in a shadehouse under 30\% shade at Stillwater and Fayetteville and 73\% shade at Park Hill on 11 May 2001. 'Emerald Gaiety' had fewer disease symptoms than 'Emerald 'n Gold' or 'Emerald Surprise' in the field and in containers at Stillwater and Fayetteville. At Fayetteville, mancozeb applied alone or in rotation with chlorothalonil or trifloxystrobin provided better anthracnose control than treatments without mancozeb, but no fungicide eliminated anthracnose symptoms. Application of fungicides in rotations that include mancozeb and use of resistant cultivars can help decrease anthracnose symptoms.

C olletotrichumgloeosporioideshas been identified as the causal organism for anthracnose on wintercreeper euonymus (Mahoney and Tattar, 1980a, 1980b). Typical symptoms include leaf lesions, leaf abscission, stem lesions, and stem dieback. During the growing season, C. gloeosporioides consists of a mass of

Approved for publication by the directors of the Oklahoma and Arkansas Agricultural Experiment Stations. The technical assistance of Beverly Webster, former technician, Department of Horticulture and Landscape Architecture, Oklahoma State University; Albert Bond, Pest Control Supervisor; and Diane Dunn, former Propagation Supervisor at Greenleaf Nursery Co., are appreciated. Greenleaf Nursery Co., Park Hill, Okla., provided partial funding, labor, fungicides, and plants for this project.

${ }^{1}$ Former graduate research assistant, Department of Horticulture and Landscape Architecture, Oklahoma State University, Stillwater, OK 74078-6027.

${ }^{2}$ Professor, Department of Horticulture and Landscape Architecture, Oklahoma State University, Stillwater, OK 74078-6027. To whom reprint requests should be addressed: e-mail janet.cole@okstate.edu.

${ }^{3}$ Former Assistant Professor, Department of Horticulture, University of Arkansas, Fayetteville, AR 72701.

${ }^{4}$ Professor, Department of Entomology and Plant Pathology, Oklahoma State University, Stillwater, OK 74078. hyphae within lesions on the stem and leaf tissue, which produces conidia on the host surface that cause secondary infection (Agrios, 1997; Alexopoulos et al., 1996). Colletotrichum gloeosporioides reinfects its host throughout the growing season by producing conidia in acervuli below the cuticle surface. The cuticle eventually ruptures and releases more conidia, allowing the disease to spread to other plants (Agrios, 1997; Alexopoulos et al., 1996). Conidia can spread by wind, insects, or in splashing water from rain or overhead irrigation. Colletotrichum gloeosporioides is capable of overwintering as mycelium in infected host tissue (Agrios, 1997) and can survive in the soil for a few weeks (Ekefan et al., 2000). Past research has shown that environmental conditions such as high night temperatures and high light intensities favor disease development on wintercreeper euonymus (Ningen et al., 2004, 2005).

Several fungicides have been tested for control of C.gloeosporioides on wintercreeper euonymus. Mahoney and Tattar (1980a, 1980b) showed that maneb, mancozeb, and chlorothalonil controlled C. gloeosporioides on wintercreeper euonymus 'Emerald 'n Gold'. Benomyl reduced symptoms, but some lesions developed (Mahoney and Tattar, 1980a, 1980b).

Growers have suggested that some chemicals are less effective at controlling C. gloeosporioides in routine fungicide spray schedules than they once were, suggesting that C.gloeosporioides may have developed some fungicide resistance. In vitro studies using leaf and stem lesions from four Connecticut nurseries showed that Colletotrichum gloeosporioides was resistant to iprodione and thiophanate methyl, while varying levels of resistance to chlorothalonil were noted (LaMondia, 2001a, 2001b). LaMondia (2001a) examined fungicidal management of anthracnose on wintercreeper euonymus and concluded that combinations of fungicides were more effective at controlling C.gloeosporioides than the same fungicides used alone. Cole et al. (2005) observed that chlorothalonil, trifloxystrobin, and mancozeb were most effective in reducing symptoms of C. gloeosporioides, but none of the fungicides completely controlled the fungus at rates and timing used.

The objective of this study was to determine the efficacy of chlorothalonil, mancozeb, and trifloxystrobin applied alone or in rotations for controlling anthracnose in field and container production of wintercreeper euonymus. Three cultivars were tested to determine cultivar tolerance to $C$. gloeosporioides. Typical nursery cultural practices were used whenever possible to generate results applicable to current management programs.

\begin{tabular}{llll}
\hline $\begin{array}{l}\text { Units } \\
\text { To convert U.S. to SI, } \\
\text { multiply by }\end{array}$ & U.S. unit & SI unit & $\begin{array}{l}\text { To convert SI to U.S., } \\
\text { multiply by }\end{array}$ \\
\hline 29.5735 & $\mathrm{fl} \mathrm{oz}$ & $\mathrm{mL}$ & 0.0338 \\
3.7854 & gal & $\mathrm{L}$ & 0.2642 \\
25.4000 & inch $(\mathrm{es})$ & $\mathrm{mm}$ & 0.0394 \\
119.8264 & $\mathrm{lb} / \mathrm{gal}$ & $\mathrm{g} \cdot \mathrm{L}^{-1}$ & 0.0083 \\
$\left({ }^{\circ} \mathrm{F}-32\right) \div 1.8$ & ${ }^{\circ} \mathrm{F}$ & ${ }^{\circ} \mathrm{C}$ & $\left(1.8 \times{ }^{\circ} \mathrm{C}\right)+32$
\end{tabular}




\section{Materials and methods}

Uniform rooted cuttings from anthracnose-infected mother plants of wintercreeper euonymus 'Emerald Gaiety', 'Emerald 'n Gold', and 'Emerald Surprise' (Greenleaf Nursery Co., Park Hill, Okla.) were tested in field and container studies. High disease incidence in the field at the time that cuttings were taken eliminated the need to further inoculate.

Symptomatic leaves and stems were collected from plants in field and container studies throughout the growing season and cultured on potato dextrose agar to confirm the causal organism. Plants were hand-sheared on 21 May, 25 June, and 17 July 2001 using the standard nursery practice at Greenleaf Nursery Co. About 25\% of the plant was removed using nonsterilized hand shears. Shearing tools are often not sterilized at nurseries, and the disease can be transmitted by shearing.

Field and container plants were sprayed to runoff with water (control, no fungicide), chlorothalonil (Echo 720; Sipcam Agro, Roswell, Ga.) at $211 \mathrm{~g} \cdot \mathrm{L}^{-1}$ a.i., mancozeb [Fore (Rohm and Haas, Philadelphia) at Stillwater and Fayetteville and Protect (Cleary Chemical Corp., Dayton, N.J.) at Park Hill $]$ at $1.4 \mathrm{~g} \cdot \mathrm{L}^{-1}$ a.i., or trifloxystrobin (Compass; Bayer Corp., Kansas City, Mo.) at $0.3 \mathrm{~g} \cdot \mathrm{L}^{-1}$ a.i. Fungicides were applied alone or in rotations of two or three fungicides. Fungicides were applied using the longest labeled spray interval for each product. Chlorothalonil and trifloxystrobin were sprayed at 14-d intervals while mancozeb was sprayed at 7 -d intervals. Chlorothalonil and trifloxystrobin were applied in alternate weeks. Control plants were sprayed to runoff with tap water at 7-d intervals. Fungicide and water treatments were applied with a carbon dioxide-pressurized backpack sprayer with an output of $670 \mathrm{~mL} \cdot \mathrm{min}^{-1}$. Plants were first sprayed on 15 May 2001 and last sprayed on 10 Sept. 2001.

Plants were visually rated for disease symptoms at 4-week intervals beginning 15 May 2001 using a modification of an assessment key for common leafspot (Phoma medicaginis) of alfalfa (Medicago sativa) [Key No. 2.2 (James, 1971)] on a scale of 0 to 100 with $0=$ a plant with no visual lesions and $100=$ defoliation. Plants with disease ratings greater than about
10 (about $10 \%$ of the plant having disease symptoms) would be considered nonsalable by many growers. The study was terminated at all sites on 10 Sept. 2001.

A split plot design with 10 replications was used for field and container studies. Fungicide was the main plot (eight treatments) while cultivar was the subplot (three cultivars). Data were analyzed using analysis of variance (SAS Institute, Cary, N.C.). Means of significant interactions and main effects were separated using a protected least significant difference (LSD) procedure.

FIELD STUDY. Cuttings were transplanted from 1-gal plastic containers into Norge loam (fine-silty, mixed, thermic, Udic Paleustol) field soil at the Oklahoma State University Nursery Research Station, Stillwater, and into Captina silt loam (fine-silty, siliceous, active, mesic, Typic Fragiudults) field soil at the University of Arkansas Horticulture Farm, Fayetteville, on 10 May 2001. Soil tests at both sites prior to planting showed no mineral deficiencies so no supplemental fertilizer was applied at either site.

Weed control was by cultivating between rows, hand-weeding within rows, and applying glyphosphate (Roundup Pro; Monsanto Co., St. Louis) at $2.7 \mathrm{lb} / \mathrm{gal}$ a.i. with a wick applicator. Plants were irrigated with drip irrigation as needed. Daily high and low temperatures and rainfall were documented (Table l). Photosynthetic photon flux $(P P F)$ was determined periodically using an integrating quantum/radiometer/photometer (model No. LI-188B; LI-COR,
Lincoln, Nebr.). Maximum PPF was $1503 \mu \mathrm{mol} \cdot \mathrm{m}^{-2} \cdot \mathrm{s}^{-1}$ at plant height at Stillwater and $1329 \mu \mathrm{mol} \cdot \mathrm{m}^{-2} \cdot \mathrm{s}^{-1}$ at plant height at Fayetteville.

Container study. Cuttings were planted into l-gal containers with substrate consisting of 6 pine bark : 1 sand amended with $5 \mathrm{lb} /$ yard $^{3}$ dolomitic lime, $10 \mathrm{oz} /$ yard $^{3} 0 \mathrm{~N}-19.8 \mathrm{P}-0 \mathrm{~K}$ (triple superphosphate), $5 \mathrm{oz} /$ yard $^{3}$ $0 \mathrm{~N}-0 \mathrm{P}-49.8 \mathrm{~K}$ (potassium chloride), 3 oz/yard ${ }^{3}$ trace elements [Frit $504 \mathrm{HF}$; Frit (UK) Ltd., Cambridge, U.K.], 1.5 $\mathrm{lb} /$ yard $^{3}$ ferrous sulfate, $1.2 \mathrm{lb} /$ yard $^{3}$ $46 \mathrm{~N}-0 \mathrm{P}-0 \mathrm{~K}$ (urea), and $2 \mathrm{lb} /$ yard $^{3}$ iron oxide (GU-49; Master Builders, Cleveland, Ohio) and placed under $30 \%$ shade at the Oklahoma State University Nursery Research Station (Stillwater) and at the University of Arkansas Horticulture Farm (Fayetteville) (maximum PPF was 1070 $\mu \mathrm{mol} \cdot \mathrm{m}^{-2} \cdot \mathrm{s}^{-1}$ and $952 \mu \mathrm{mol} \cdot \mathrm{m}^{-2} \cdot \mathrm{s}^{-1}$ at plant height, respectively) and under $73 \%$ shade (maximum PPF was $435 \mu \mathrm{mol} \cdot \mathrm{m}^{-2} \cdot \mathrm{s}^{-1}$ at plant height) at Greenleaf Nursery Co. (Park Hill). Trifluralin plus isoxaben (Snapshot; Dow AgroSciences, Indianapolis) was applied to container media at 4.6 $\mathrm{lb} / 1000 \mathrm{ft}^{2}$ on 21 May 2001 to control weeds. Containers were hand-weeded as needed, and plants were irrigated daily with about 1 inch of water using overhead sprinkler irrigation. Daily high and low temperatures and rainfall were documented (Table 2).

\section{Results}

Field study, Stillwater. No significant interaction between fungicide and cultivar occurred for disease ratings in June, July, or August. During

Table 1. Average daily high and low temperatures and total rainfall between rating dates for anthracnose damage on wintercreeper euonymus in field fungicide studies at Stillwater, Okla., and Fayetteville, Ark., in full sun.

\begin{tabular}{|c|c|c|c|c|}
\hline \multirow[b]{2}{*}{ Location } & \multirow[b]{2}{*}{ Rating period } & \multicolumn{2}{|c|}{$\begin{array}{l}\text { Avg daily temp } \\
\left({ }^{\circ} \mathrm{C} \pm \mathrm{SE}\right)^{\mathrm{z}}\end{array}$} & \multirow{2}{*}{$\begin{array}{c}\text { Total } \\
\text { rainfall } \\
\text { (inches) }^{\mathrm{y}}\end{array}$} \\
\hline & & High & Low & \\
\hline \multirow[t]{4}{*}{ Stillwater } & 15 May-13 June 2001 & $39.0 \pm 0.9$ & $16.2 \pm 1.0$ & 5.75 \\
\hline & 14 June-10 July 2001 & $42.6 \pm 0.7$ & $19.5 \pm 0.5$ & --- \\
\hline & 11 July-14 Aug. 2001 & $46.9 \pm 0.5$ & $22.7 \pm 0.3$ & 3.63 \\
\hline & 15 Aug.-10 Sept. 2001 & $41.9 \pm 0.5$ & $20.0 \pm 0.3$ & 2.32 \\
\hline \multirow[t]{4}{*}{ Fayetteville } & 15 May-12 June 2001 & $25.3 \pm 1.6$ & $15.2 \pm 1.9$ & 4.64 \\
\hline & 13 June-10 July 2001 & $30.1 \pm 0.9$ & $19.6 \pm 0.9$ & 3.86 \\
\hline & 11 July-7 Aug. 2001 & $33.0 \pm 1.0$ & $22.6 \pm 1.1$ & 3.83 \\
\hline & 8 Aug.-4 Sept. 2001 & $31.9 \pm 0.6$ & $20.6 \pm 0.7$ & 2.73 \\
\hline
\end{tabular}

${ }^{2}$ Plants were rated on the ending date of each time period. Average daily high and low temperatures were calculated by summing the daily high and low temperatures, respectively, and dividing by the number of days in the time period; $\left(1.8 \times{ }^{\circ} \mathrm{C}\right)+32={ }^{\circ} \mathrm{F}$.

'Rainfall data were missing for several dates in late June at Stillwater, so rainfall data were not included for this rating period; 1 inch $=25.4 \mathrm{~mm}$. 
these months, disease ratings differed among cultivars but not among fungicides. Disease symptoms were less on 'Emerald Gaiety' $(2.5,6.3,7.7)$ than 'Emerald 'n Gold' $(6.7,10.6,14.6)$ or 'Emerald Surprise' $(6.3,9.3,13.3)$ in June, July, and August, respectively $\left(\mathrm{LSD}_{0.05}=1.6,1.6\right.$, and 1.7 for June, July, and August, respectively).

A significant interaction existed between fungicide and cultivar in September disease ratings (Table 3 ). Regardless of fungicide treatment used, 'Emerald Gaiety' plants had lower disease ratings than 'Emerald 'n Gold' or 'Emerald Surprise' plants receiving the same treatments. 'Emerald 'n Gold' and 'Emerald Surprise' plants receiving chlorothalonil, chlorothalonil and mancozeb, mancozeb and trifloxystrobin, or chlorothalonil, trifloxystrobin, and mancozeb did not differ in disease ratings within fungicide treatment. 'Emerald Gaiety' plants receiving chlorothalonil and mancozeb, chlorothalonil and trifloxystrobin, mancozeb and trifloxystrobin, or chlorothalonil, trifloxystrobin, and mancozeb did not differ in disease ratings among fungicide treatments and had lower disease ratings than the same cultivar receiving chlorothalonil, mancozeb, trifloxystrobin, or water. The lowest disease ratings for 'Emerald 'n Gold' plants occurred when plants were treated with chlorothalonil and trifloxystrobin or mancozeb and trifloxystrobin. 'Emerald Surprise' plants treated with mancozeb, trifloxystrobin, chlorothalonil and trifloxystrobin, or mancozeb and trifloxystrobin had lower disease ratings than 'Emerald Surprise' plants receiving any other fungicide treatment.

Field study, Fayetteville. No significant interactions existed between cultivar and fungicide for disease ratings in May, June, or July (data not presented). Disease ratings did not differ among cultivars or among fungicide treatments in May, June, or July (data not presented).

A significant interaction existed between fungicide and cultivar in disease ratings in August (Table 4). Plants receiving any fungicide treatment had lower disease ratings than water control plants. 'Emerald 'n Gold' plants treated with chlorothalonil, trifloxystrobin, or chlorothalonil and trifloxystrobin had higher disease ratings than 'Emerald Gaiety' or 'Emerald Surprise' receiving
Table 2. Average daily high and low temperatures and total rainfall between rating dates for anthracnose damage on wintercreeper euonymus in container fungicide studies at Stillwater, Okla., and Fayetteville, Ark., under 30\% shade and under $73 \%$ shade at Park Hill, Okla.

\begin{tabular}{|c|c|c|c|c|}
\hline \multirow[b]{2}{*}{ Location } & \multirow[b]{2}{*}{ Rating period } & \multicolumn{2}{|c|}{$\begin{array}{l}\text { Avg daily temp } \\
\quad\left({ }^{\circ} \mathrm{C} \pm \mathrm{SE}\right)^{\mathrm{z}}\end{array}$} & \multirow{2}{*}{$\begin{array}{c}\text { Total } \\
\text { rainfall } \\
\text { (inches) }^{\mathrm{y}}\end{array}$} \\
\hline & & High & Low & \\
\hline \multirow{4}{*}{ Stillwater } & 15 May-13 June 2001 & $34.3 \pm 0.9$ & $16.2 \pm 1.0$ & 5.75 \\
\hline & 14 June-10 July 2001 & $38.4 \pm 0.6$ & $19.7 \pm 0.5$ & --- \\
\hline & 11 July-14 Aug. 2001 & $42.0 \pm 0.5$ & $22.4 \pm 0.2$ & 3.63 \\
\hline & 15 Aug.-10 Sept. 2001 & $38.8 \pm 0.6$ & $20.1 \pm 0.2$ & 2.32 \\
\hline \multirow[t]{4}{*}{ Fayetteville } & 15 May-12 June 2001 & $25.0 \pm 1.3$ & $15.0 \pm 1.1$ & 4.64 \\
\hline & 13 June-10 July 2001 & $30.0 \pm 0.8$ & $19.4 \pm 0.8$ & 3.86 \\
\hline & 11 July-7 Aug. 2001 & $33.3 \pm 0.9$ & $22.8 \pm 0.4$ & 3.83 \\
\hline & 8 Aug. -4 Sept. 2001 & $31.7 \pm 0.6$ & $20.6 \pm 0.6$ & 2.73 \\
\hline \multirow[t]{4}{*}{ Park Hill } & 15 May-12 June 2001 & $28.1 \pm 1.1$ & $16.8 \pm 1.2$ & 6.57 \\
\hline & 13 June-12 July 2001 & $30.1 \pm 0.8$ & $20.4 \pm 0.9$ & 4.45 \\
\hline & 13 July-7 Aug. 2001 & $33.9 \pm 0.7$ & $22.8 \pm 0.6$ & 1.54 \\
\hline & 8 Aug.-12 Sept. 2001 & $29.7 \pm 0.9$ & $21.1 \pm 0.5$ & 7.15 \\
\hline
\end{tabular}

${ }^{2}$ Plants were rated on the ending date of each time period. Average daily high and low temperatures were calculated by summing the daily high and low temperatures, respectively, and dividing by the number of days in the time period; $\left(1.8 \times{ }^{\circ} \mathrm{C}\right)+32={ }^{\circ} \mathrm{F}$.

"Rainfall data were missing for several dates in late June at Stillwater, so rainfall data were not included for this rating period; 1 inch $=25.4 \mathrm{~mm}$.

Table 3. Disease ratings in Sept. 2001 of three cultivars of wintercreeper euonymus grown in the field and treated with various fungicides alone and in rotations at Stillwater, Okla. $(\mathbf{n}=10)$.

\begin{tabular}{|c|c|c|}
\hline Fungicide treatment & Cultivar & Disease rating $^{\mathrm{z}}$ \\
\hline \multirow[t]{3}{*}{ Chlorothalonil } & Emerald 'n Gold & 17.0 \\
\hline & Emerald Gaiety & 8.7 \\
\hline & Emerald Surprise & 17.0 \\
\hline \multirow[t]{3}{*}{ Mancozeb } & Emerald 'n Gold & 19.5 \\
\hline & Emerald Gaiety & 11.0 \\
\hline & Emerald Surprise & 13.0 \\
\hline \multirow[t]{3}{*}{ Trifloxystrobin } & Emerald 'n Gold & 16.5 \\
\hline & Emerald Gaiety & 11.0 \\
\hline & Emerald Surprise & 14.5 \\
\hline \multirow[t]{3}{*}{ Chlorothalonil + mancozeb } & Emerald 'n Gold & 19.0 \\
\hline & Emerald Gaiety & 7.0 \\
\hline & Emerald Surprise & 19.0 \\
\hline \multirow[t]{3}{*}{ Chlorothalonil + trifloxystrobin } & Emerald 'n Gold & 11.5 \\
\hline & Emerald Gaiety & 6.5 \\
\hline & Emerald Surprise & 13.5 \\
\hline \multirow[t]{3}{*}{ Mancozeb + trifloxystrobin } & Emerald 'n Gold & 12.5 \\
\hline & Emerald Gaiety & 6.5 \\
\hline & Emerald Surprise & 13.5 \\
\hline \multirow{3}{*}{$\begin{array}{l}\text { Chlorothalonil + trifloxystrobin } \\
+ \text { mancozeb }\end{array}$} & Emerald 'n Gold & 14.5 \\
\hline & Emerald Gaiety & 5.5 \\
\hline & Emerald Surprise & 15.5 \\
\hline \multirow[t]{3}{*}{ Water } & Emerald 'n Gold & 25.5 \\
\hline & Emerald Gaiety & 11.5 \\
\hline & Emerald Surprise & 17.0 \\
\hline \multicolumn{3}{|l|}{ Significance $\left(\operatorname{LSD}_{0.05}\right)$} \\
\hline \multicolumn{2}{|l|}{ Cultivar for same treatment } & 1.9 \\
\hline \multicolumn{2}{|l|}{ Cultivar for different treatment } & 2.1 \\
\hline
\end{tabular}


the same treatments. 'Emerald 'n Gold' and 'Emerald Gaiety' plants receiving water, mancozeb, mancozeb and trifloxystrobin, or chlorothalonil, trifloxystrobin, and mancozeb had higher disease ratings than 'Emerald Surprise' plants receiving the same fungicide treatment. Cultivars did not differ in disease ratings when the rotation of chlorothalonil and mancozeb was applied. Plants receiving the rotation of chlorothalonil and mancozeb did not differ in disease rating compared to the same cultivar receiving the rotation of mancozeb and trifloxystrobin, and these two fungicide treatments resulted in the lowest disease ratings overall.

No significant interaction occurred between cultivar and fungicide for disease ratings in September. Disease ratings differed among cultivars and among fungicide treatments in September. 'Emerald 'n Gold' plants had higher disease ratings (13.8) than 'Emerald Gaiety' (9.3) or 'Emerald Surprise' (9.4) plants $\left(\mathrm{LSD}_{0.05}=2.4\right)$. mancozeb and trifloxystrobin (2.7), chlorothalonil and mancozeb (6.3), or mancozeb and trifloxystrobin and chlorothalonil (4.0) had lower disease ratings than plants treated with water (26.2), chlorothalonil (17.5), trifloxystrobin (13.2), or chlorothalonil and trifloxystrobin (14.0) in September $\left(\mathrm{LSD}_{0.05}=8.9\right)$.

Container study, Stillwater. Disease ratings did not differ among cultivars in May, June, or July (data not presented). 'Emerald Gaiety' was damaged less $(3.0,6.5)$ than 'Emerald 'n Gold' $(7.4,13.3)$ or 'Emerald Surprise' $(8.9,17.6)$ in August and September, respectively $\left(\mathrm{LSD}_{0.05}=3.7\right.$ and 4.8 for August and September, respectively). Disease ratings did not differ among fungicide treatments in the container study on any rating date (data not presented). No interaction between cultivar and fungicide occurred among disease ratings at any rating date.

Container study, FayetTEVILle. No interaction occurred between fungicide and cultivar for disease ratings on any rating date. Disease ratings differed among fungicides and among cultivars only in September. Mancozeb alone and rotations that included mancozeb controlled anthracnose symptoms better than the water control, trifloxystrobin, chlorothalonil, or a rotation of trifloxystrobin and chlorothalonil (Table 5). Fewer anthracnose sympPlants treated with mancozeb (2.8),

Table 4. Disease ratings in Aug. 2001 of anthracnose on three cultivars of wintercreeper euonymus grown in the field and sprayed with various fungicides alone and in rotation at Fayetteville, Ark. $(n=10)$.

\begin{tabular}{|c|c|c|}
\hline Fungicide treatment & Cultivar & Disease rating $^{z}$ \\
\hline \multirow[t]{3}{*}{ Chlorothalonil } & Emerald 'n Gold & 15.0 \\
\hline & Emerald Gaiety & 4.0 \\
\hline & Emerald Surprise & 5.0 \\
\hline \multirow[t]{3}{*}{ Mancozeb } & Emerald 'n Gold & 5.5 \\
\hline & Emerald Gaiety & 6.0 \\
\hline & Emerald Surprise & 1.5 \\
\hline \multirow[t]{3}{*}{ Trifloxystrobin } & Emerald 'n Gold & 12.0 \\
\hline & Emerald Gaiety & 2.5 \\
\hline & Emerald Surprise & 3.0 \\
\hline \multirow[t]{3}{*}{ Chlorothalonil + mancozeb } & Emerald 'n Gold & 2.0 \\
\hline & Emerald Gaiety & 2.5 \\
\hline & Emerald Surprise & 1.0 \\
\hline \multirow[t]{3}{*}{ Chlorothalonil + trifloxystrobin } & Emerald 'n Gold & 10.5 \\
\hline & Emerald Gaiety & 8.5 \\
\hline & Emerald Surprise & 3.0 \\
\hline \multirow[t]{3}{*}{ Mancozeb + trifloxystrobin } & Emerald 'n Gold & 3.0 \\
\hline & Emerald Gaiety & 4.0 \\
\hline & Emerald Surprise & 0.0 \\
\hline \multirow{3}{*}{$\begin{array}{l}\text { Chlorothalonil + trifloxystrobin } \\
+ \text { mancozeb }\end{array}$} & Emerald 'n Gold & 4.5 \\
\hline & Emerald Gaiety & 7.0 \\
\hline & Emerald Surprise & 0.5 \\
\hline \multirow[t]{3}{*}{ Water } & Emerald 'n Gold & 18.0 \\
\hline & Emerald Gaiety & 19.5 \\
\hline & Emerald Surprise & 7.0 \\
\hline \multicolumn{3}{|l|}{ Significance $\left(\operatorname{LSD}_{005}\right)$} \\
\hline \multicolumn{2}{|l|}{ Cultivar for same treatment } & 2.2 \\
\hline \multicolumn{2}{|l|}{ Cultivar for different treatment } & 2.8 \\
\hline
\end{tabular}

${ }^{2}$ Anthracnose damage rating scale ranged from 0 to 100 with $0=$ no damage and $100=$ a dead plant. Plants with ratings greater than 10 would be considered nonsalable by many nurseries.

Table 5. Disease ratings in Sept. 2001 of three cultivars of wintercreeper euonymus grown in containers and treated with various fungicides alone and in rotations at Fayetteville, Ark. $[\mathrm{n}=30$ (fungicide), $\mathbf{n}=80$ (cultivar)]

\begin{tabular}{lc}
\hline Treatment & Disease rating \\
\hline \multicolumn{2}{c}{ Fungicide main effect } \\
Chlorothalonil & 22.2 \\
Mancozeb & 11.1 \\
Trifloxystrobin & 22.8 \\
Chlorothalonil + Mancozeb & 8.9 \\
Chlorothalonil + Trifloxystrobin & 23.6 \\
Mancozeb and Trifloxystrobin & 13.9 \\
Chlorothalonil + Trifloxystrobin & \\
$\quad+$ Mancozeb & 16.4 \\
Water & 36.1 \\
Significance (LSD 0.05 ) & 15.4 \\
\multicolumn{2}{c}{ Cultivar main effect } \\
Emerald 'n Gold & 23.7 \\
Emerald Gaiety & 12.0 \\
Emerald Surprise & 22.5 \\
Significance $\left(\right.$ LSD $\left._{0.05}\right)$ & 6.3 \\
\hline${ }^{2}$ Anthracnose damage rating scale ranged from 0 to 100 with $0=$ no \\
damage and $100=$ a dead plant. Plants with ratings greater than 10 \\
would be considered nonsalable by many nurseries.
\end{tabular}


toms appeared on 'Emerald Gaiety' than 'Emerald 'n Gold' or 'Emerald Surprise' (Table 5).

Container study, Park Hill. Anthracnose symptoms were minimal (ratings $<$ l) on all rating dates. Disease ratings did not differ among cultivars or fungicides in the container study at Park Hill on any rating date. No significant interaction occurred between cultivars and fungicides for disease ratings on any rating date.

\section{Discussion}

Low disease ratings and lack of differences in ratings among cultivars and among fungicide treatments in the container study at Park Hill may be attributed to the study being conducted under $73 \%$ shade. Ningen et al. (2005) found fewer anthracnose symptoms on wintercreeper euonymus grown under higher shade intensities than at lower shade intensities.

'Emerald Gaiety' generally had lower disease ratings than 'Emerald 'n Gold' or 'Emerald Surprise' at Stillwater and Fayetteville. These results were similar to those of several studies that have noted fewer anthracnose symptoms on 'Emerald Gaiety' than on 'Emerald 'n Gold' (Mahoney and Tattar, 1980a, 1980b; Ningen et al., 2004, 2005). LaMondia (2001a) found that 'Emerald 'n Gold' had more lesions per leaf, but defoliation was greater on 'Emerald Gaiety'.

Mahoney and Tattar (1980a, $1980 \mathrm{~b}$ ) found that mancozeb and chlorothalonil completely controlled C.gloeosporioides on wintercreeper euonymus 'Emerald 'n Gold'. Our results differed from those of Mahoney and Tattar (1980a, 1980b) in that mancozeb and chlorothalonil suppressed anthracnose symptoms but did not provide complete control. LaMondia (200la, 200lb) also noted varying amounts of resistance of C. gloeosporioides to chlorothalonil in vitro.

LaMondia (2001a, 2001b) suggested that combinations of fungicides with different modes of action might be more effective at controlling $C$. gloeosporioides on wintercreeper euonymus than the same fungicides used alone. Each of the fungicides tested in this study had a different mode of action. Chlorothalonil is an aromatic hydrocarbon protectant fungicide that reacts with thiol groups in the enzyme systems of fungi (Hutson and Miyamoto, 1998). Mancozeb is an organic, protectant fungicide that converts to ethylene diisothiocyanate and reacts with enzymatic sulfhydryl groups (Copping and Hewitt, 1998). It inhibits enzyme activity in metal-containing enzymes that are involved with production of adenosine triphosphate (ATP) (Copping and Hewitt, 1998, Hutson and Miyamoto, 1998). Trifloxystrobin interferes with mitochondrial respiration of the pathogenic fungus (Copping and Hewitt, 1998). Results of our research indicate that fungicide rotations, particularly those containing mancozeb, were more effective at reducing anthracnose symptoms on wintercreeper euonymus than each fungicide alone.

From this study, use of resistant cultivars is recommended when possible. Fungicide rotations that include mancozeb help decrease but do not eliminate disease symptoms. Implementing cultural practices such as growing under shade with afternoon irrigation (Ningen et al., 2005) can also reduce disease incidence.

\section{Literature cited}

Agrios, G.N. 1997. Plant pathology. 4th ed. Academic Press. San Diego.

Alexopoulos, C.J., C.W. Mims, and M. Blackwell. 1996. Introductory mycology. 4th ed. Wiley, New York.

Cole, J.T., J.C. Cole, and K.E. Conway. 2005. Effectiveness of selected fungicides applied with or without surfactant in controlling anthracnose on three cultivars of Euonymus fortunei. J. Appl. Hort. $7(1): 16-19$.
Copping, L.G. and H.G. Hewitt. 1998. Chemistry and mode of action of crop protection agents. Royal Soc. Chem., Cambridge, U.K.

Ekefan, E.J., S.A. Simons, A.O. Nwankiti, and J.C. Peters. 2000. Semi-selective medium for isolation of Colletotrichum gloeosporioides from soil. Expt. Agr. 36:313-321.

Hutson, D. and J. Miyamoto. 1998. Fungicidal activity: Chemical and biological approaches to plant protection. Wiley, West Sussex, England.

James, W.C. 1971. A manual of assessment keys for plant diseases. Can. Dept. Agr. Publ. No. 1458. Amer. Phytopathol. Soc., St. Paul, Minn.

LaMondia, J.A. 200la. Management of euonymus anthracnose and fungicide resistance in Colletotrichum gloeosporioides by alternating or mixing fungicides. J. Environ. Hort. 19:51-55.

LaMondia, J.A. 2001b. Resistance of euonymus anthracnose pathogen, Colletotrichum gloeosporioides, to selected fungicides. J. Environ. Hort. 19:47-50.

Mahoney, M.J. and T.A. Tattar. 1980a. Causal organism for spot anthracnose disease identified. Amer. Nurseryman 152(13):77-78.

Mahoney, M.J. and T.A. Tattar. 1980b. Identification, etiology and control of Euonymus fortunei anthracnose caused by Colletotrichum gloeosporioides. Plant Dis. 64:854-856.

Ningen, S.S., J.C. Cole, and K.E. Conway. 2004. Cultivar and night temperature affect severity of anthracnose on Enonymus fortunei. HortScience 39:230-231.

Ningen, S.S., J.C. Cole, M.W. Smith, D.E. Dunn, and K.E. Conway. 2005. Increased shade intensity and afternoon irrigation decrease anthracnose severity on three Euonymus fortunei cultivars. HortScience 40:111-113. 